BIBLID: 0015-1807, 47 (2020), 2 (pp. 39-61)

UDK 811.18:811.14:811.163.41]'373.7

https://doi.org/10.18485/fpregled.2020.47.2.3

\author{
Predrag Mutavdžić \\ Univerzitet u Beogradu - Filološki fakultet \\ predrag.mutavdzic@fil.bg.ac.rs \\ Merima Krijezi \\ Univerzitet u Beogradu - Filološki fakultet \\ kmerima@sezampro.rs \\ Ana Sivački \\ Univerzitet u Beogradu - Filološki fakultet \\ anasivacki@yahoo.com
}

\title{
MESEC U FRAZEOLOGIZMIMA U SAVREMENOM ALBANSKOM, GRČKOM I SRPSKOM JEZIKU*
}

\begin{abstract}
Apstrakt: Kao Zemljin pratilac, Mesec je, poput Sunca, važan u životu svakog živog bića, s obzirom na to da utiče na njih. Gledajući i iz mitološke perspektive, lunarni kult nije samo prisutan, već i duboko utemeljen kod svih naroda čije frazeološke korpuse kontrastiramo. Stoga je i cilj našeg rada da utvrdimo koliko su frazeološke konstrukcije koje sadrže ključnu reč mesec u albanskom, grčkom i srpskom jeziku međusobno podudarne, odnosno da utvrdimo putem kontrastivne i komparativne analize u kom se stepenu između ovih frazeoloških koncepcija javljaju podudarnosti i nepodudarnosti kako na morfosintaksičkom polju, tako i na semantičkom, imajući u vidu da se u frazeologizmima znatno proširuje njegova semantika. Pritom, naša je analiza usmerena i na etno-mitološko kontrastiranje pomoću kojeg bi se omogućio uvid i u stepen kulturološko-tradicijske podudarnosti relevantnih aspekata posmatranih jezičkih sistema.
\end{abstract}

Ključne reči: Mesec, frazeologizmi, narodna verovanja, albanski, grčki, srpski, ekvivalencija.

\begin{abstract}
Abstrakt: Being the Earth's companion, the Moon bears importance for any living being similar to the one that the Sun has owing to its effect exerted thereon. From the mythological perspective, the lunar cult is not only present but deeply rooted in all the peoples the phraseological corpuses of which we have contrasted. Therefore, the objective of our paper is to determine the level of concordance amongst phraseological units containing the key constituent moon in Albanian, Greek and Serbian, i. e. to determine, by employing contrastive and comparative analysis, to what extent there are concordances and discordances both in the morphological-syntactic and semantic respect, while having in mind that their meaning is significantly expanded within phraseologisms. Furthermore, our
\end{abstract}

* Rad je napisan u okviru projekta Ministarstva nauke, obrazovanja i tehničkog napretka Republike Srbije Jezici i kulture u vremenu i prostoru (broj 178002). 
analysis is directed towards ethnological and mythological contrasting by means of which insight would be provided into the level of culturological and traditional concordance of relevant aspects of the observed language systems.

Keywords: moon, idiomatic expressions, popular beliefs, Albanian, Greek, Serbian, equivalence.

\section{Cilj i metodologija rada, korpus}

Glavni cilj našeg rada ${ }^{1}$ predstavlja kontrastivno i komparativno sagledavanje kako unutrašnje (morfosintaksičke) strukture frazeologizama formiranih putem ključne reči $\underline{\text { mesec }}$ u tri nesrodna savremena balkanska jezika - albanskom, grčkom i srpskom - tako i spoljašnjeg (semantičkog) polja koji svaki frazeologizam poseduje. Budući da komparativni pristup zahteva sagledavanja iz različitih pravaca, polazni jezik može biti svaki od navedenih, s obzirom na to da se u svakome od njih frazeološka slika gradi na drukčiji način, sledeći one principe koji su za taj jezik od značaja.

Zbog potrebe rada i metodološke doslednosti, sve idiomatske sklopove nazivamo dvojako - frazeologizmi i frazeološke konstrukcije - ne zalazeći u sva teorijska tumačenja u vezi sa njihovim imenovanjima, klasifikacijama i shvatanjima datim u relevantnoj frazeološkoj literaturi. U frazeologizme svrstavamo i paremije - njih nekoliko koliko smo pronašli-koje se, po svojim karakteristikama, znatno približavaju frazeološkim konstrukcijama, budući takođe čvrste i ustaljene strukture i značenja ${ }^{2}$. Isto tako, nastojimo da, bez obzira na smer kretanja:

a) sagledamo u kojoj meri postoji podudarnost između posmatranih frazeologizama;

б) iznađemo najbolji prevodni ekvivalent (odnosno, semantički parnjak);

в) uvidimo da li je i u kom obimu moguće govoriti o međujezičkoj, međuleksičkoj i međusemantičkoj podudarnosti.

Strukturna i semantička podudarnost kontrastiranih frazeoloških jedinica sagledava se putem ustaljenog trostepenog načina klasifikacije ekvivalencije: potpunog, delimičnog i nultog. Svi primeri s nultim stepenom strukturno-seman-

${ }^{1}$ Ovaj rad, u vidu referata, izložen je u opštim crtama na međunarodnoj naučnoj konferenciji Gjuha shqipe në kontakt me gjuhët e tjera (,Albanski jezik u dodiru sa drugim jezicima”) održanoj 6. decembra 2017. na Fakultetu za istoriju i lingvistiku Univerziteta u Tirani. Za štampanu verziju na srpskom dopunjen je i znatno proširen.

${ }^{2}$ Da li se paremije sagledavaju kao frazeologizmi ili ne, postoje različita mišljenja, a mi smo se priklonili onima koja ih uvrštavaju u zaseban frazeološki fond (cf: Dragana Mršević-Radović, Frazelološke glagolsko-imeničke sintagme u savremenom srpskohrvatskom jeziku. Edicija Monografija. Knjiga LX, Beograd, Filološki fakultet, 1987, str. 28; Zlata Bojović, „Paremije u književnom delu”. U: Srbistički prilozi - Zbornik u čast profesora Slavka Vukomanovića /urednici: Božo Ćorić, Ljubomir Popović, Brankica Čigoja, Aleksandar Milovanović/. Beograd, Filološki fakultet, 2005, str. 52; Rajna Dragićević, „Koncept Boga u srpskim narodnim poslovicama”. U: Teoligvistička proučavanja slovenskih jezika /urednice: Jasmina Grković-Mejdžor i Ksenija Končarević/. Odeljenje jezika i književnosti. Srpski jezik u svetlu savremenih lingvističkih teorija. Knjiga 5, Beograd, SANU, 2013, str. 72; Anđelka Pejović, Paremije kao deo etnolingvističkog nasleđa. Glasnik Etnografskog instituta SANU, 62/2 /2014/, str. 202). 
tičke ekvivalencije označeni su asteriskom, a podvučeni su oni gde se uočava delimična strukturna podudarnost. Radi što jasnijeg uvida u frazeološku situaciju i radi ilustacije i argumentovanosti, svi primeri na albanskom i grčkom jeziku dati su kao glose (u zagradama su njihovi doslovni prevodi). Na kraju rada naveli smo i nekoliko narodnih zagonetki na sva tri jezika koje, i pored toga što po svojoj formi nisu deo frazeologije, čine jedan od važnih etnografskih i kulturoloških segmenata svakog naroda. Njihovim uvrštenjem smo želeli da, makar u najgrubljim crtama, zaokružimo pogled na značaj i ulogu Meseca kod sva tri pomenuta balkanska naroda.

Kada je reč o izvorima iz kojih smo crpeli građu za analizu frazeologizama sa leksemom mesec, oslanjali smo se prvenstveno na nama sve dostupne rečnike - opšte i frazeološke - uključujući i one u vidu celih izdanja kao online verzije. Njihov spisak priložen je na kraju rada. Sekundarni vid provere upotrebe i značenja frazeologizama iz korpusa čini Google pretraživač. ${ }^{3}$

\section{Uvodno razmatranje}

Usmerenost čoveka prema nebu, odnosno prema najvažnijim vidljivim nebeskim telima, i to (uslovno rečeno) relativno bliskim, Suncu i Mesecu, te znatno udaljenim, zvezdama, postoji u svakoj kulturi, a ispoljava se kroz sačuvana mnogobrojna verovanja, običaje, kultne i obredne radnje, razne mitske priče i legende. Kako je svojevremeno naznačio naš ugledni etnograf Veselin Čajkanović, „,код Грка и Римљана каткад наилазимо на веровање (на пример, код Вергилија) да душе покојника живе на Месецу“, 4 a kada je reč o Srbima, „наши преци интересовали су се месецом и звездама само у питањима магије и пољопривредног календара. Они су могли знати известан број митова о небеским телима, али култа није било“. 5 Jednu od drevnih magijskih kultnih radnji predstavlja i takozvani srpski način gatanja u vidu hidromantije, ili hvatanje punog Meseca u tepsiji sa vodom - kod antičkih Grka mesečev odraz se hvatao putem ogledala - običaj koji je dugo postojao u predelima istočne Srbije i koji je, po istom autoru, „иако много доцнијег времена, оригиналнији од грчког“. 6

Kao osnovni ili sporedni sadržalac i ovih i drugih etnoloških elemenata javlja se svako od ovih tela, u zavisnosti od toga da li pripada području dnevnog ili noćnog neba, dobivši vremenom posebnu simboliku i značaj. Sunce i Mesec su izjednačeni s određenim božanstvom, pri čemu je ime planete bilo ujedno i ime samog božan-

\footnotetext{
${ }^{3}$ Hteli bismo da naznačimo da Google, ili bilo koji drugi internet pretraživač, još ne može ponuditi dovoljan broj jezičkih primera niti konteksta upotrebe svih zabeleženih frazeologizama.

${ }^{4}$ Веселин Чајкановић, Мит и религија у Срба (приредио Војислав Ђурић), Београд, СКЗ, 1973, стр. 44.

${ }^{5}$ Веселин Чајкановић, „,'Пуштање воде' о Великом четвртку”. У: Студије из религије и фолклора, Београд, Српски етнографски зборник, књига XXXI, Живот и обичаји, књига 13, Београд: СКА, 1924, стр. 80.

${ }^{6}$ Веселин Чајкановић, „Хидромантија код Филипа Вишњића”. У: Зборник у славу Филипа Вишњића и народне песме, Београд, 1936, стр. 93-94.
} 
stva. U bezmalo svim poznatim mitološkim predstavama, Sunce se prikazuje kao izrazito moćan simbol, kao onaj koji daruje život i koji svojom snagom jednako pogađa sve pripadnike jednog društva, pa otuda nosi sve atribute koji ga svrstavaju u kategoriju vigoroznog muškog božanstva. Poput Sunca, i Mesec na nebu vozi svoje kočije - u Homerovoj Himni Seleni (Eıৎ $\Sigma \varepsilon \lambda \eta ́ v \eta v)^{7}$ u desetom stihu navodi se da ih vuku ,dugogrivi konji”. Za razliku od Sunca, Mesec se doživljava kao mnogo nežniji, suptilniji i krhkiji element i svrstava se u kategoriju ženskih simbola. Dodatni motiv za ovakvo posmatranje nalazimo u još dve činjenice:

- prva je ta da Mesec nema svoj izvor svetlosti, što u percepciji stvara konotaciju njegove zavisnosti. U velikom broju narodnih pesama i priča Sunce i Mesec se posmatraju kao muž i žena, pri čemu se za Mesec, kao ženu, implicira zavisnost od supruga;

- druga se tiče same ženske prirode - nestalnost ženskog karaktera, odnosno promena raspoloženja i njena ćud. Mogućnost da se na ženu lako utiče, objašnjavala se putem mesečevih mena: u istoj meri u kojoj su mene promenljive i nestabilne, u tolikoj meri je promenljiva i nestalna ženska ćud.

I kod Albanaca Mesec je predstavljen kao žena, a Sunce kao muškarac: tako se u jednoj pesmi legendaranog tipa kod italijanskih Arbreša (Arëbreshët) ${ }^{8}$ devojka sreće s aždajom na Aždajinoj planini koja je, čim je saznala da je kćerka „sunca i meseca” (otac joj je sunce, a mati mesec), odustala od namere da je pojede, te ju je pustila uz pozdrave. ${ }^{9}$ Da je Mesec zaista smatran pravim ženskim simbolom, potvrđuje i naredni albanski frazeologizam jam në hënë të fëmijës (= „,biti u/na detetovom mesecu”) u kome se podvlači drugo stanje žene i period njenog neposrednog porođaja. Koliko smo uspeli da utvrdimo, ni u jednom drugom evropskom jeziku ovakav frazeološki opis ne postoji. U indoevropskoj mitologiji Mesec je sagledavan kao simbol ženskog božanstva, s obzirom na to da ima mogućnost da samog sebe 'porodi', odnosno da se čudotvorno obnovi, te se u tom pogledu izjednačava sa ženom: samome sebi 'podaruje' iznova život na isti način kao što žena može podariti nov život. Kao i žena, tako i Mesec u ovom frazeologizmu oličava pasivan i plodan element. Tesnu vezanost majke s detetom opisuje i naredna paremija koju smo jedino u albanskom pronašli - fëmija pa nënë si nata pa hënë (= „dete bez majke kao noć bez meseca”) - koja veoma poetski, metaforički i slikovito daje prikaz situacije u kojoj je dete ostalo (sasvim

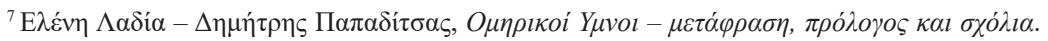

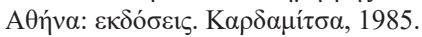

${ }^{8}$ Ovaj etnonim se odnosi na stanovnike Italije albanskog porekla, koji su delove (uglavnom južne) Italije u najvećoj meri naselili tokom 15. stoleća, odnosno nakon Skenderbegove smrti. U srpskim dokumentima iz srednjeg veka Albanci se navode kao Arbanasi (kao što stoji u Zakoniku cara Dušana, na primer, u članu 82; videti u: Душанов законик, Београд, Ганеша клуб, 2016, str. 71).

${ }^{9}$ Këngë popullore legjendare (Zgjedhur e pajisur me shënime nga Q. Haxhihasani), Instituti i shkencave, Tiranë, 1955, str. 91. 
ili je u nekom kraćem vremenskom periodu) bez majke. U paremiji opisuje se prirodna uzročno-posledična veza, pri čemu je lik majke sasvim izjednačen sa likom noći - obe su antropomorfne i personifikovane u činu rađanja, izuzev što svaka na svoj način rađa svoje čedo: majka dete, a noć Mesec. Povezivanje majke i Meseca moguće je na osnovu dva drevna shvatanja: prvog, na koji smo već ukazali, da je Mesec simbol ženskog božanstva, i drugog, da su na nebu sve zvezde „deca Meseca”.

Zbog svojih mena, Mesec se u velikom broju kultura smatra(o) simbolom neprekidnog rađanja i umiranja, odnosno neprekidne reinkarnacije života koja se može odvijati jedino na tom nebeskom telu. Otuda su lunarna božanstva, poput Persefone kod antičkih Grka, najčešče i htonsko-smrtna. Kako je Elijade svojevremeno naznačio, Mesec je

„telo koje nastaje, nestaje i gubi se, telo koje je ponajmanje podvrgnuto univerzalnom zakonu nastajanja, rođenja i umiranja. Mesec, poput čoveka, uključen je u tragediju /.../ ali njegova 'smrt' /.../ nikada nije konačna /.../ Ovo neprekidno vraćanje na svoj početak i ovaj nikad okončani ciklus čini mesec jedinim nebeskim telom koji je tesno povezano sa našim ritmom života /.../ On vlada svim sferama prirode koja potpadaju pod zakon nikad okončanog ciklusa: vodom, kišom, biljnim svetom, plodnošću“ “. ${ }^{10}$

Ujedno, Mesec je i simbol prolaznosti života, odnosno vremena, sagledano u najširem obimu. U islamu i hrišćanstvu, solarni i lunarni kalendar prate jedan drugoga: dok je u hrišćanstvu lunarni kalendar bitan pri određenju datuma Uskrsa, u islamu se nijedan važan datum ne može zamisliti bez lunarnog kalendara. U Kur'anu se Mesec (arapski qamar) veoma često navodi i, poput Sunca, i on je jedan od Alahovih ispoljavanja znamenja (41: 37, 280 ${ }^{11}$ ). Kako ga je Alah stvorio $(10: 5,108 ; 29: 61,230 ; 35: 13,250)$, Mesec mu odaje počast pokoravajući mu se $(7: 54,82 ; 13: 2,133)$ i klanjajući mu se $(22: 18,186)$. Alah ga je potčinio čoveku $(14: 33,139)$ da bi računao vreme putem mesečevih mena (6: 96, 73; 36: 39, 254) i razdoblja (2: 185). Na Sudnji dan, odnosno kada dođe smak sveta, Mesec će se sasvim zamračiti i zajedno sa Suncem ugasiti (75: 8-9, 360). U Rimu na Avetinu postojao je mali hram boginje Lune, koga je prema legendarnom predanju podigao u 6. veku pre Hrista kralj Servije Tulije (Servius Tullius, $\dagger$ oko 543) ${ }^{12}$, gde su se poslednjeg dana marta svake godine organizovale svetkovine boginji u čast čime se simbolično označavao početak nove godine prema starom rimskom kalendaru. Ove proslave redovno su se str. 154

${ }^{10}$ Mircea Eliade, Patterns in Comparative Religion. London-New York: Sheed \& Ward, 1958,

${ }^{11}$ Prvi broj ukazuje na suru, drugi ukazuje na stih unutar sure, a treći je broj stranice na kojoj se nalazi. Za ovu priliku smo se poslužili prevodom Kur' 'ana Besima Korkuta (Sarajevo, El-Kelimeh, 1987).

${ }^{12}$ Emil Aust, "Luna". U: Ausführiches Lexikon der griechischen und römischen Mythologie (Wilchelm Heinrich Roscher, Hgst.). Zweiter Band 2, Zweite Abteilung, Laas - Mython. Leipzig, B. G. Treubner, 1897, str. 2154. 
održavale sve do 153. godine pre Hrista. U okviru računanja dana u sedmici, proslava Meseca je u rimskom kalendaru padala odmah posle dana proslave Sunca, kao najvažnijeg rimskog kulta, pa se otuda dies Lunae smatrao drugim danom sedmice. U potonjoj evropskoj kulturnoj tradiciji u mnogim jezicima zadržan je rimski način imenovanja dana u vidu njihovih doslovnih prevoda, te otuda u albanskom kalk e hënë kojim se imenuje ponedeljak.

Kada je reč o protoku, ili odmeravanju protoka vremena, u mnogim kulturama se periodi ženske plodnosti neposredno povezuju sa određenim mesečevim menama, a kod Slovena i Grka se verovalo da Mesec direktno utiče na žensku plodnost. Slično verovanje postojalo je i kod drevnih Dačana: njihova boginja Bendis bila je boginja Meseca, šuma, noći i braka, ${ }^{13}$ pa shodno tome i plodnosti. U cilju slavljenja ženske plodnosti, kod Kineza je dugo bio zadržan običaj da se $\mathrm{u}$ vreme jesenje ravnodnevice, koja pada petnaestog dana osmoga meseca prema kineskom kalendaru, održava svetkovina gde je muškarcima bilo zabranjeno prisustvovanje, a žene i devojke su donosile svoje darove u voću i kolačima posebno pravljenim za tu priliku zajedno sa granama amaranta. ${ }^{14}$ Mesec je i simbol hladnog, odmerenog znanja, životne mudrosti, koja se stiče postepeno i dugo. Kako se u pojedinim kulturma, kao što je antička grčka, sova vezuje za mudrost, otuda je usledila povezanost između nje i Meseca.

\section{Nekoliko reči o Mesecu u narodnim verovanjima kod Albanaca, Grka i Srba}

U slovenskoj mitologiji, sačuvanoj u oskudnim izvorima u odnosu na grčku i rimsku, vladalo je verovanje da su Mesec i Sunce bili vlasništvo vrhovnog boga Peruna, pošto ih je stvorio i na nebo svojevoljno postavio. Verovatno je zato kod Slovena sačuvan običaj da se ove dve planete ne psuju niti proklinju, pošto se smatralo da će doneti zlo onome koji ih uzima u usta. ${ }^{15}$ Baš kao i u rumunskim zemljama, i na području Albanije brakovi su tradicionalno proslavljani uglavnom $\mathrm{u}$ vreme punog meseca da bi se obezbedio zdrav porod, a svako prerano rođenje deteta je u Elbasanu nazivano ,,indje pa hënë" (= „rođenje bez meseca”). ${ }^{16} \mathrm{Za}$ sever Albanije bilo je karakteristično verovanje da će odojče, ako pogleda u Mesec, odmah dobiti dijareju, ${ }^{17}$ što svakako ima veze sa rasprostranjenim balkanskim na-

\footnotetext{
${ }^{13}$ Ioan Petru Culianu - Cicerone Poghirc, „Bendis”. U: Cult, magie, erezii. Articole din enciclopedii ale religiilor (editor științific: Culianu I. P.). Iaşi, Polirom, 2003, str. 54-55.

${ }^{14}$ Mythologies des montagnes, des forêts et des îles. Éditeur général Pierre Grimal. Paris: Larousse Reliure, 1963, str. 126-127.

${ }^{15}$ Međutim, kod Srba se ipak mogu čuti psovke u kojima se pominje uglavnom Sunce (cf: jebem ti sunce žarko / krvavo; sunce ti kalajisano i slično).

${ }^{16}$ Ekrem Čabej, ,Život i običaji Arbanasa”. Knjiga o Balkanu 1. Beograd, Balkanski institut, 1936, str. 303-306.

${ }^{17}$ Činjenica da 'pogled u Mesec' izaziva dijareju, veoma je zanimljiva s obzirom da se u albanskom jeziku frazeologizam sëmundja (lëngata) e hënës odnosi na epilepsiju (v. u nastavku teksta).
} 
rodnim verovanjem u urokljive oči ${ }^{18}$ - Mesec se može posmatrati i kao svojevrsno nebesko oko koje je u stanju da svojim moćima utiče na slaba i nemoćna bića. U mnogim kulturama primećeno je da se takozvano mesečarenje, somnabulizam, uglavnom javlja pri punom mesecu (iako svakako ne samo tada), što je pripisano čudnim silama Meseca, ili uticajima duhova predaka ili demonima noći. Kod Srba je dugo postojalo ukorenjeno verovanje da trudnica nikada ne sme zaspati na otvorenom $-\mathrm{u}$ protivnom rodiće mesečara. ${ }^{19}$ Međutim, ukoliko se za vreme punog meseca potapšemo po džepu, ili ukoliko u noći punog meseca otvorimo prazan novčanik i usmerimo ga prema Mesecu, te kažemo devet puta „napuni ga”, smatralo se da ćemo imati novca. Ovo drevno verovanje potiče iz perioda kada se mislilo da je Mesec sačinjen od srebra, te da poseduje moć da privlači novac.

Opšteg je karaktera ustaljeno verovanje da se čovek može preobraziti u vukodlaka tokom noći punog Meseca, a kod Grka se u narodnoj mitologiji ustalilo shvatanje da se tokom takve noći javljaju i epileptični napadi kao i sklonost ka samoubistvu. I kod Albanaca i kod Grka pojava epilepsije se takođe dovodi u vezu sa pojavom punog Meseca, što se vidi u njenom narodnom imenovanju kao punë (semundja / lëngata) e hënës (= „mesečevo delo (rabota) / bolest meseca”), odnosno kod Grka kao $\sigma \varepsilon \lambda \eta v \imath \alpha \sigma \mu o ́ \varsigma$ (= „mesečarstvo”). U jednoj albanskoj narodnoj legendi iz Laberije pripoveda se zašto je Mesečev sjaj slabiji u odnosu na Sunčev: nekada su i Mesec i Sunce istom snagom sijali, ali su se jednom posvađali, te ga je Sunce tako jako ošamarilo, da mu je ispalo jedno oko, pa zato danas Mesec nema toliki sjaj kao Sunce. ${ }^{20}$ Odvajkada se u svim kulturama pomračenje Meseca i Sunca posmatra kao zlokoban trenutak, pa su zato Albanci na severu pucali iz svih oružja da oteraju vampire koji su se okomili na njega da ga pojedu. ${ }^{21}$ Pojava mladog meseca je izazivala drukčiju reakciju, posebno kod dece i devojaka u albanskim planinskim krajevima: kako je mlad mesec simbol čednosti, upućivane su mu molbe za uspeh i sreću u životu u vidu magičnih formula, poput naredne:

Hënë e re, vashë e re! $!^{22}$

Unë në punë e ti në gjumë,

Unë shëndet e ti gërshet! ${ }^{23}$

${ }^{18}$ Ramiz Fiçorri, Mati. Vështrim i shkurtër gjeologjik, historik, eknomik, kulturor, Tiranë, Dardania, 1998, U: Robert, Elsie. A Dictionary of Albanian Religion, Mythology, and Folk Culture. New York, New York University Press, 2001, str. 181.

${ }^{19}$ Žarko Trebješanin, Predstave o detetu u srpskoj tradicionalnoj kulturi. Beograd, Sofos, 1991.

${ }^{20}$ Kolë Kamsi. Besime të popullit në Labëri. Dituria No. 8 (1928), str. 309-310.

${ }^{21}$ Drita Halimi-Statovci, Etnologjia flet. Prishtinë: Instituti Albanologjik, 1998, str. 205-206.

${ }^{22}$ Jani Nushi, Mitologji e besime në Myzeqe (me një parathënie nga Mark Titrja), Etnografia Shqiptare, No. 5 (1974), str. 336.

${ }^{23}$ Prevod formule je naš i nije doslovan, već smo nastojali da bude što verodostojniji duhu na albanskom:

Mlada luno, devojče puno!

Ja u poslu, a ti u mom snu,

Ja krepko, a ti sjajno tako! 
u kojima poseban efekat ostavljaju kako pažljivo formulsani simetrični jampski stihovi u vidu leonijske rime i vezanog ritma tako i suptilna slikovita poređenja (kao u konkretnom primeru). Iz svega rečenog može se zaključiti da Albanci veoma poštuju Mesec i da prema njemu imaju gotovo isti odnos kao prema Suncu: u izvesnom smislu, Mesec je i kod ovog naroda svojevrsni antipod Suncu, podjednako važan kako za verovanja i svakodnevne različite mitološke, ritualne i obredne radnje, tako i u frazeološkom okruženju, na šta ćemo se posebno osvrnuti u nastavku.

Kod Grka u jednoj narodnoj dečijoj pesmi, koja glasi:

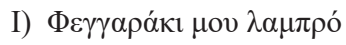

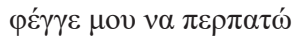

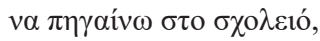

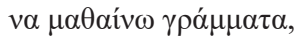
$\gamma \rho \alpha ́ \mu \mu \alpha \tau \alpha, \sigma \pi \mathrm{ov \delta \alpha ́} \gamma \mu \alpha \tau \alpha$,

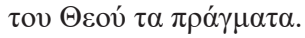

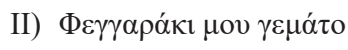

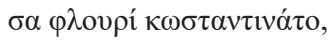
$\varphi \varepsilon ́ \gamma \gamma \varepsilon \mu \mathrm{ov} \tau \omega ́ \rho \alpha \sigma \tau \eta \sigma \tau \rho \alpha ́ \tau \alpha$,

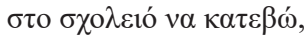

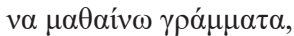
$\gamma \rho \alpha ́ \mu \mu \alpha \tau \alpha, \sigma \pi о v \delta \alpha ́ \gamma \mu \alpha \tau \alpha$,

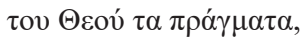

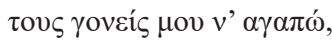

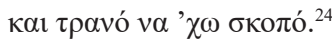

glavni motiv jeste dečije prizivanje Meseca i njegovih moći: Mesecu je pripisana posebna simbolična ritualno-magijska funkcija zaštite, prosvećenja i blagodarivanja, i to bezmalo na isti onaj način kao što majka svoje dete blagosilja, hrabri i nastoji da zaštiti.

\section{O konceptima frazeologizama sa leksemom mesec u savremenom albanskom, grčkom i srpskom jeziku}

Ekscerpcija frazeologizama iz korpusa na sva tri jezika pruža sledeću sliku: najveći broj je zabeležen u albanskom - 39 primera, u grčkom tek sedam, a u srpskom svega pet.

Ukoliko imamo na umu potpunu strukturno-semantičku ekvivalenciju, ona je vidljiva u svega jednom primeru:

\footnotetext{
${ }^{24}$ Prepev pesme je naš:

I) Meseče moj mali, put mi ti osvetli, dok $u$ školu idem ja, da učim slova ta sva, sve što treba da se zna, a po Bogu da se ravna.

II) Meseče moj veliki, kao dukat presvetli, svetli mi na svodu tom, u školu idem korakom, da učim slova ta sva, sve što treba da se zna, a po Bogu da se ravna, roditelje svoje volim ja, sve do kraja, beskraja.
}

Zanimljivo bi bilo navesti da je ova dečija pesma veoma omiljena te da se izvodi u bezmalo istom ritmu i melodiji kao naša Taši taši tanana. 


\section{leh në hënë ${ }^{25}$ \\ lajati na mesec / zvezde

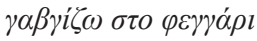

u kojem se iznosi očevidno narodno saznanje da psi, kao i vukovi, umeju da laju / zavijaju na mesec. U raširenom balkanskom (pa i evropskom) verovanju lajanje na mesec je obično bilo shvaćeno kao nagoveštavaj ili nečije bliske smrti ili kao kakvo predskazanje zla. U metaforičkom pogledu, sagledano na nivou odnosa čoveka prema čoveku, lajanje psa sagledava se kao „nerazumni govor”, odnosno kao rezaumljivo (nemušto) obraćanje, koje je u isti mah i uzaludno zbog postojanja velike udaljenosti između Meseca i psa, te zato Mesec ne može da „čuje” ono što mu pas ,govori”. U narodnoj filozofiji se svaki oblik udaljenog fizičkog prostora, u ovom slučaju iskazan nebeskim telom, obično izjednačava s otežanim sporazumevanjem, što jasno podvlači koncept (konotaciju) neshvatanja i nerazumevanja, a u nešto širem pogledu i uzaludnog trošenja vremena i reči.

U narednom frazeološkom primeru na albanskom ndërroj si hëna (=,,menjati se kao mesec") koncept promenljivosti čovekovog karaktera / ponašanja dovodi se u očiglednu vezu s promenom mesečevih mena, čime je moguće istovremeno izraziti i trenutnu i stalnu karakternu osobinu nečije nestalnosti ili prevrtljivosti. Njegovi odgovarajući srpski i grčki prevodni ekvivalenti:

*okretati se kako vetar duva / menjati kao Ciganin konje

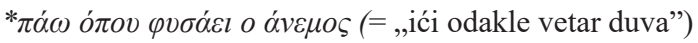

u odnosu na albanski polazni frazeologizam, osim što su semantički izjednačeni, strukturno su sasvim različiti, te otuda pripadaju kategoriji nulte podudarnosti. Bez obzira na to što poneka promena može biti i pozitivna, ovaj frazeologizam ipak figurira u okviru negativnog semantičkog polja.

U albanskoj frazeološkoj konstrukciji kam rënë nga hëna (= „pasti sa Meseca"), uočava se koncept odsustva obaveštenosti unutar koga se Mesec simbolički posmatra kao udaljeno prebivalište u poređenju sa Zemljom, našim realnim okruženjem i staništem. Sâm frazeologizam je tako koncipiran da ukazuje na smeštanje translatornog linearnog kretanja u okviru poznatog koordinatnog sistema shvatanja prostora, pri čemu se Mesec doživljava kao polazna tačka u obliku „drugog”, „onostranog”, nesaznatog i neodređenog sveta. U tom pogledu objektivni faktor ogromne prostorne razdaljine figurira kao svojevrsni kodni šum: zbog nje, protok i razmena informacija i svih saznanja u potpunosti je onemogućen. Kako se Mesec sagledava kao svet za sebe i po sebi, izolovan i udaljen od naše realnosti i događaja u njoj, prostorna udaljenost postaje shvaćena kao

${ }^{25}$ Upredivo sa: to bark at the moon / to bay the moon, abbaiare alla luna, a lătra la luna, den Mond anbellen, ugatja a holdat (mađarski) itd. 
svojevrsna jedinica, odnosno srazmera nečije neobaveštenosti, neupućenosti. Ova kosmička razdaljina prikazuje ili pruža doživljaj naglog silaska sa visine, što se metaforčki sagledava kao opis iznenadne promene okruženja i prostorne dimenzije koja se može, u skladu sa našim subjektivnim doživljajem, gradirati u jeziku (cf: pasti na teme / sa kruške / sa Meseca / sa Marsa). Opis prostornog gradacijskog udaljavanja, od bližeg ka dalekom unutar ove frazeološke konstrukcije ima za cilj da hiperbolički i slikovito pokaže kako nivoe logičkog i semantičkog poimanja razlike, tako i subjektivnu težinu u iznošenju našeg neprijatnog iznenađenja ili razočaranja zbog nečije neobaveštenosti, neupućenosti, neukosti i slično.

U odnosu na ostale balkanske jezike, još jedino u rumunskom i u bugarskom navedena albanska konstrukcija ima svoj odgovarajući podudarni semantičko-strukturni ekvivalent:

a fi căzut din luna / a trăi în luпӑ = паднал од луната

dok se u srpskom i grčkom zapaža delimična strukturna nepodudarnost u pogledu izbora leksema: u srpskom najčešće figurira Mars, mada postoji i varijanta sa Mesecem, a u grčkom nebeski svod:

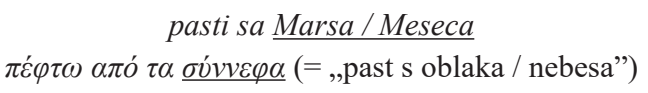

Mesec se, zbog svojih mena, posmatra i kao poseban koncept autodestruktivnosti ispoljene u vidu sposobnosti da samog sebe 'jede', pa otuda u srpskom frazeologizam jesti se kao pun mesec koji je zabeležen samo u ovom jeziku. Njegovo je metaforičko značenje da ukaže na čoveka ophrvanog brigama ili zlom, te zbog toga samom sebi nanosi psihičku štetu (patnju). Dakle, u pitanju je iskazivanje posebnog negativnog emotivnog i/ili duševnog stanja, ali treba ukazati i na činjenicu da se Mesec kroz svoje mene ponovo rađa i obnavlja, što se može uporediti sa situacijama u kojima se u svakodnevnom životu upotrebljava navedeni frazeologizam na srpskom u tom smislu da svaka patnja, ljutnja, bes i sve ono zbog čega se čovek 'jede' ima svoje cikluse i prolaznog je karaktera. U grčkom se zapaža donekle slična konstrukcija, s tom razlikom što je frazeološka komponenta iskazana drugom leksemom: $\tau \rho \omega ́ \gamma \varepsilon \tau \alpha l \mu \varepsilon \tau \alpha \rho o v ́ \chi \alpha ~ \tau o v(=$, jesti se sa svojom odećom"), dok joj je semantičko značenje nepromenjeno. U albanskom se kao odgovarajući ekvivalent javlja ili opisni nefrazeološki izraz *indinjohet për hiçmosgjë (=,ljutiti se ni zbog čega") ili drugi frazeološki tip - ha këmbët e veta (= ,jesti svoje noge"), kod kojeg se metonimijskom zamenom na relaciji ČOVEK $\rightarrow$ NOGA iskazuje semantički potpuno podudaran koncept.

I u albanskom i u grčkom zapazili smo po jednu frazeološku konstrukciju sa leksemom mesec koje se dovode u direktnu vezu sa čovekovim unutrašnjim stanjem u vidu koncepta iskazivanja samosvojstvenosti: 
(është) njeri me hënë / hënëz (= ,/jeste/ čovek sa mesecem”)

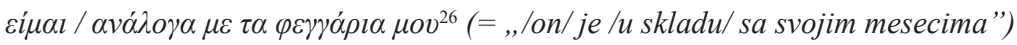

*biti na svoju ruku

što se, kao i u jednom od prethodnih primera, može objasniti putem promena mesečevih mena (otuda u grčkom množina). Ovde faktor samodestruktivnosti nije toliko ispoljen, već se više insistira logički i semantički na isticanju nečijeg osobenjaštva i neuklapanja u okvire. Frazeologizacija se ne zasniva na pukom povlačenju paralela između karakteristika ovog nebeskog tela i karakteristika čoveka kojima se one pripisuju, već se zalazi dublje u tumačenje uticaja Meseca na čovekovo ponašanje, odnosno na njegovu osobenost. I za mnoge kulture širom sveta karakteristično je verovanje da Mesec i njegove mene imaju takvu moć da mogu upravljati našim životima, sledstveno i čovekovim ponašanjem. Upravo je ovakva vrsta prirodne i fizičke nestalnosti, kao najprepoznatljivija odlika Meseca, omogućila da se u albanskom i grčkom narodnom tumačenju pojavi shvatanje kako se svako odudaranje od uobičajenog i društveno prihvatljivog ponašanja (kao što su osobenjaci) ili neka vrsta (trenutnog, nesvakidašnjeg) čudnog ponašasanja, poput rđave volje, mrzovoljnosti, može objasniti samo putem direktnog uticaja Meseca.

Kada je reč o konceptu ukazivanja na međuljudske odnose, za albanski su karakteristični i naredni frazeologizmi:

A) jam me hënë të keqe / $\underline{\text { të }}$ mire (= „biti sa lošim / dobrim mesecem”) - njegovo značenje može biti ili negativno ili pozitivno, sve u zavisnosti od atributske dopune.

Na srpski i na grčki prenosi se opisno, odnosno sasvim drugim oblicima frazeologizacije koji su, sa strukturne tačke, posebni za svaki jezik, iako se mogu uočiti izvesne podudarnosti:

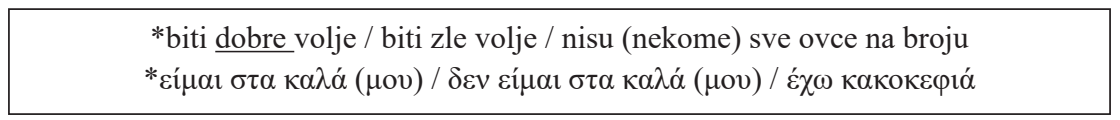

Koliko nam je poznato, još jedino u italijanskom i španskom jeziku postoji frazeološka konstrukcija sa leksemom mesec koja, kao i albanska, takođe ukazuje na rđavo raspoloženje i emotivno stanje - avere la luna di traverso ili estar de mala luna (u značenju: „ustati na levu nogu”). Dodajmo još i to da su Aristotel i Plinije Stariji u svojim spisima zaista smatrali kako je ljudski mozak veoma podložan uticajima Meseca, budući da je „najvlažnije” mesto u ljudskom organizmu, te da

\footnotetext{
${ }^{26}$ Uporediti s italijanskim frazeologizmom: ha la luna (di traverso) (= „ima mesec /u prolazu/”).
} 
na isti način kako Mesec utiče na plimu i oseku, tako utiče i na ljudski mozak, prouzrokujući tada razna i ponekad neshvatljiva emocionalna i psihička stanja.

B) janë parë me hënabrenda (=,videli su se s mesecom unutra / unutarmesecom”)

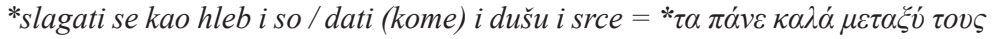

C) janë parë me hënë të keqe / hënajashtë (=,videli su se sa rđavim mesecem / vanmesecem")

*ne mogu se očima gledati / slažu se kao pas i mačka

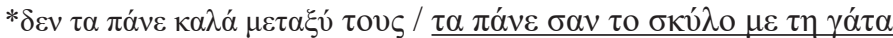

S obzirom na to da ljudsko društvo karakterišu najrazličitije vrste međuljudskih odnosa, kao i da između ljudi postoji izvestan stepen antipatičnosti i simpatičnosti, privlačenja i odbijanja, navedeni albanski frazeologizmi nastoje da poetski i plastično opišu dva najčešća tipa tih odnosa. U prvom slučaju reč je o slaganju, a u drugom o neslaganju. Kao povod za nastanak ovih frazeologizama poslužile su same mesečeve mene, odnosno sâm Mesec, za koga se verovalo, kako smo naznačili, da ima sposobnost kontrole i upravljanja našim životima. Koliko smo upoznati, do danas se još jedino kod Albanaca zadržalo drevno shvatanje da je Mesec svojevrsno „kosmičko oko” koje je, baš kao i ljudsko, u stanju da začara ljude i da na njih baci zlu magiju i zavadu. Otuda, kada njega na nebu nema, odnosi između ljudi su dobri, ali kada se pojavi kao pun i bude bliži nama, što se optički nekada tako čini, tada je u mogućnosti da baca svoje čini, odnosno da na ljude gleda „urokljivo”, što posledično remeti odnose u zajednici (bilo unutar porodice ili šire). Frazeologizam pod C) odnosi se na verovanje, dokumentovano i kod antičkih Grka u mitu o Hekabi Trioditis, da je pun mesec zapravo „mračan”, budući da se identifikuje sa podzemljem, odnosno sa duhovima, mrtvima, vradžbinama i zlim proročanstvima, te da se upravo u vreme punog meseca pojavljuju utvare, vampiri i vukodlaci.

D) e shikoj / vështroj (dikë) si ujku hënën (=, ,gledati /koga/ kao vuk mesec”) *(po)gledati (koga) popreko / mrko; ošinuti (koga) pogledom $={ }^{*} \kappa \varepsilon \rho \alpha v v o \beta o \lambda \omega ́$ (кóлоเоv) $\mu \varepsilon \beta \lambda \varepsilon \dot{\mu} \mu \alpha \alpha$

U odnosu na sve savremene balkanske i evropske jezike, ovo je takođe jedna od posebnosti albanske frazeološke slike u kojoj se Mesec dovodi u neposrednu vezu sa vukom, životinjom koja se u indoevropskoj mitologiji posmatra i kao „utvara” i kao biće divljih i opasnih sila, za koje se smatralo da „guta” svetlost Meseca, zbog čega dolazi do pomračenja. ${ }^{27} \mathrm{Iz}$ tog razloga, kada ga čovek pogleda, u trenutku ostaje paralisan i bez moći govora. Vučji pogled u ovoj frazeološkoj

${ }^{27}$ Словенска митологија, енцииклопедијски речник. (С. Толстој / Љ. Раденковић, уредници). Београд, Zepter Book, 2001, str. 354. 
konstrukciji mogao bi se protumačiti najpre kao iskaz nepoverenja i straha od mesečeve svetlosti - kao što je poznato, to je životinja koja lovi najčešće noću, pod okriljem tame, Mesec je njegov neprijatelj, budući da ga u lovu može lako otkriti. Kako ni vuk nije bespomoćan, pošto poseduje svoje magične moći, „baca poseban pogled" na Mesec kako bi ga „omađijao” i tako oterao sa nebeskog svoda. I ovde se podvlači prastaro verovanje u sposobnost oka, odnosno pogleda, da može negativno delovati na čoveka i okolinu. Ova izvorna motivisanost nastanka frazeologizma prenesena je na polje odnosa čoveka prema čoveku, noseći jasnu implikaciju prekornog ili mrskog pogleda. Kako se vuk u narodnim tumačenjima dovodi u vezu i sa mračnim natprirodnim silama kojima služi, veza između njega i Meseca postaje još čvršća, ukoliko celu konstrukciju posmatramo kao prikaz odmeravanja moći i jednog i drugog - vuka, kao tamnog elementa, i Meseca, kao svetlog. Njihova suprotstavljenost utoliko je izraženija, ukoliko se u obzir uzme staro verovanje po kome je vuk suvereni „,vladar htonskog sveta”, a Mesec „vladar sveta noći”.

Samo u albanskom (među analiziranim jezicima) se Mesec vezuje i za koncept prekomernog traženja (odnosno, zahtevanja, izvoljevanja), što izražava frazeologizam kërkoj hënën (= ,tražiti mesec”) čiji odgovarajući strukturno-semantički pandani u engleskom, francuskom, italijanskom i rumunskom jeziku glase: to ask for the moon; demander la lune; chiedere la luna; a cere / a vrea luna de pe cer. U srpskom i grčkom jeziku, međutim, ovaj koncept ima drukčije leksičko proširenje, u smislu da se kao predikatske dopune pojavljuju nebeski svod i zvezde:

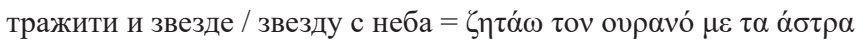

U sva tri jezika se ovim konstrukcijama nedvosmisleno podvlači nečija pohlepa, nezasitost i/ili gramzivost. U odnosu na albanski, srpski i grčki primeri pokazuju delimičnu strukturnu, a potpuno istu semantičku vrednost. Motivisanost nastanka ovog frazeologizma je i više nego jasna - nastao je iz praktične potrebe da se opiše nečija nerealna želja za posedovanjem nečega što se objektivno posedovati ne može. Dodatno, ne bi trebalo smetnuti s uma ni činjenicu da se nekada verovalo kako je Mesec bio sazdan od čistog srebra od koga su se u srednjem veku najčešće kovali novčići. Tako je Mesec metaforički sagledan i kao nedostižan izvor ekonomske moći (srebra) i socijalnog blagostanja.

Za označavanje koncepta nekog vremenskog perioda koji je definisan bilo kao duži ili kao kraći u sva tri jezika uočava se niz frazeologizama koji između sebe uglavnom nisu podudarni u strukturnom pogledu - premda izražavaju isti smisao, njihov način frazeologizacije je poseban u svakom jeziku, te su u tom

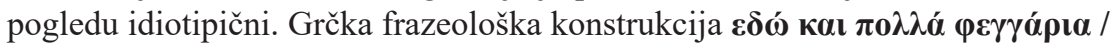

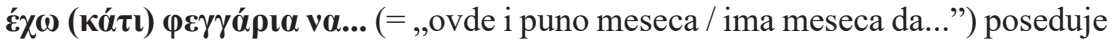
svoju najpribližniju ekvivalenciju u engleskoj adverbijalnoj konstrukciji many 
moons ago, dok su u srpskom i u albanskom njeni najpribližniji prevodni ekvivalenti dati samo nefrazeološki i opisno:

*prošlo je mnogo vremena da... = * ka shumë kohë që...

Za grčki i srpski jezik karakteristične su dve naredne frazeološke konstrukcije koje takođe ukazuju na neodređeni period trajanja, ili na jasan kraj (završetak) trajanja, a koje se na ciljne jezike mogu preneti jedino putem drukčijih tipova frazeologizacije ili nefrazeološki:

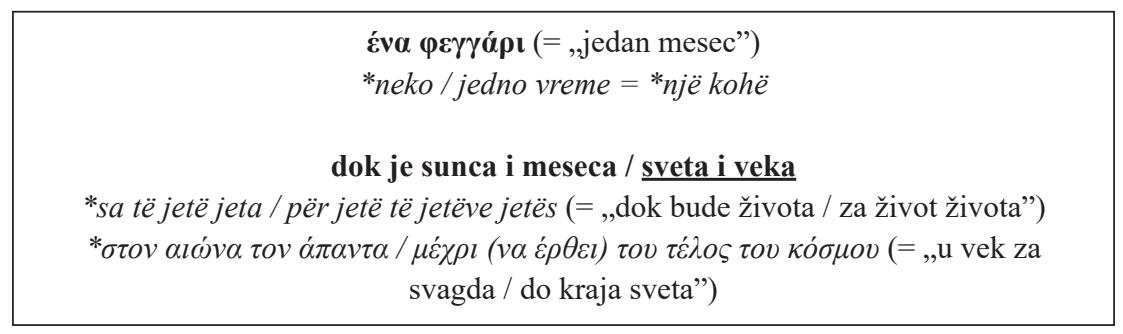

U oba slučaja reč je o narodnoj filozofiji poimanja mesta i uloge čoveka u svetu i kosmosu, odnosno o shvatanju da je ljudski život veoma kratak i prolazan, nestalan te da, u odnosu na njega, postoje neki drugi smerljivi i stabilniji, postojaniji i neprolazni elementi, poput Meseca i Sunca, koji se ne mogu lako uništiti. Isto tako, čovekova je realna potreba da meri protok vremena, pa je Mesec, zbog svojih mena, u tom pogledu bio mnogo pogodniji i očigledniji u odnosu na Sunce. Mesec i njegove redovne mene poslužile su i za izgrađivanje koncepta odnosa vremenskog okvira koji se (relativno) retko događa, pa otuda naredne frazeološke konstrukcije u sva tri jezika:

një herë në hënë / si hëna për bajram (= ,jednom na mesec / kao mesec na bajram”)

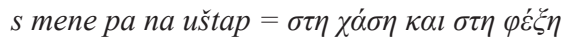

Kako se vidi iz primera, srpski i grčki jezik iskazuju potpunu strukturno-semantičku podudarnost, dok su u odnosu na albanski strukturno potpuno nepodudarni, a semantički mu se samo približavaju. Glavna motivacija nastanka ovakvog iskazivanja koncepta vremena nalazi se u činjenici da je potrebno da prođe izvesno vreme kako bi od mladog meseca nastao pun, što se izjednačava sa čvrstim cikličnim, odnosno ustaljenim, ponavljanjem tačnih vremenskih sekvenci.

Koncept bede, nemaštine i siromaštva se jedino u albanskom među posmatranim jezicima iskazuje putem sledećeg frazeologizma: 


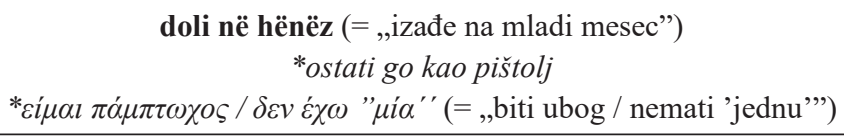

u kome mlad mesec i simbolički i metaforički ukazuje na to da se neko nalazi (uslovno rečeno) tamo gde je nekada bio, na početku. Ustaljeno se u mnogim kulturama mlad mesec posmatra u konotaciji ponovnog rađanja i obnove, pa je najverovatnije iz te $\mathrm{i}$ takve motivisanosti nastala ova albanska konstrukcija, i pored toga što joj je danas značenje isključivo negativno, budući da ukazuje na nečiju ekonomsku propast. Naznačimo i to da je simbolika mladog meseca bila odvajkada (i to ne samo u indoevropskoj kulturi) pozitivna, pošto je on oličenje perioda kada valja započeti ili pokrenuti neki posao, dok se faza punog mesec sasvim suprotno shvata. Kako se u mitološkim predstavama Mesec najčešće dovodi u vezi sa simbolima mračnog i tamnog, ovakav odnos prenesen je i na polje frazeologije, što pokazuju ukazane konstrukcije.

Nadovezujući se na prethoni, i koncept uzaludnog truda iskazuje se putem simbolike mladog meseca: u albanskom iskazuje ga frazeološka konstrukcija flas në hënëz (=, govoriti na mlad mesec") čiji su prevodni ekvivalenti u grčkom i srpskom apsolutno podudarni semantički, a samo delimično podudarni strukturno:

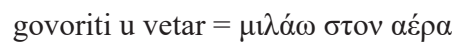

Kao sinonimna se u albanskom vrlo često čuje i konstrukcija flas në erë / hava / tym (= ,govoriti u vetar / vazduh / dim") koja je u ovom pogledu sasvim podudarna sa navedenim srpskim i grčkim frazeologizmima. Kao i u prethodnom primeru, i ovde mlad mesec nosi negativnu konotaciju. Po svemu sudeći, nastanak ovog frazeologizma u vezi je sa pokušajem ukazivanja na prostornu udaljenost između sagovornika, u smislu da sve što se nekome kaže ne dopire do njegovih ušiju. Mesec se tako s objektivnog određenja kao veoma udaljenog i nedostižnog prostora spušta na nivo subjektivnog određenja prostorne udaljenosti, pri čemu dolazi do motivisanog metaforičkog pomeranja fokusa sa sagovornika prema Mesecu i do njihovih izjednačavanja. Ovaj albanski frazeologizam suprotan je već pomenutoj frazeološkoj konstrukciji kam rënë nga hëna, ali između njih ipak postoji znak jednakosti - bez obzira što se ovde prostor sagledava u suprotnom smeru, prema Mesecu, u oba frazeologizma glavnu poentu čini daljina, odnosno subjektivno prikazana udaljenost koja direktno utiče na odnos između dva čoveka.

Kod Grka i Srba, ali i kod Italijana, postoji nominalna frazeološka konstrukcija u kojoj je Mesec poistovećen sa ljudskim licem:

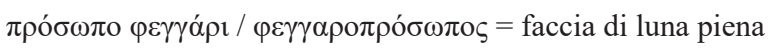

mesečevo lice 
Ni u ovoj nominalnoj konstrukciji leksema mesec ne sadrži pozitivnu konotaciju: okruglo, zaobljeno lice se ne posmatra kao zdravo, već je ono, po pravilu, bez boje (bledo) i, sledstveno, bolesno, bilo zbog preterane gojaznosti, bilo zbog pojave otečenosti (nadutosti) usled nekog nezdravog stanja organizma (bolest, upotreba lekova i slično). Motivacija za ovakvu konotaciju Meseca počiva na pronalaženju simbolične sličnosti između punog lica i faze punog mesečevog kruga. I u albanskom smo zabeležili frazeologizam motivisan fizičkim karakteristikama Meseca, koje se direktno preslikavaju na opis fizičkih karakteristika čoveka (najčešće žene). Međutim, oblik punog meseca slikovito motiviše frazeologizam

(si) hënë e plotë (=,/kao/ pun mesec”)

*(kao) rumena jabuka

čija je konotacija pozitivna, što se može videti na osnovu toga da izraz figurira u semantičkom polju ZDRAVLJE / FIZIČKA LEPOTA. Ovaj primer predstavlja očiglednu potvrdu dominacije Meseca kao 'ženskog' elementa, odnosno našeg polaznog zapažanja da se kod Albanaca ovo nebesko telo reprezentuje kao žena.

U albanskom frazeološka paremijska konstrukcija e kam bërë lëmë më lëmë e hënë më hënë (=, napraviti gumno za gumno a mesec za mesec”) nosi takođe negativan smisao, budući da ukazuje na koncept rđavo izvedenog posla. Njegovi prevodni ekvivalenti na srpskom i na grčkom pripadaju drugim oblicima frazeologizacije, pošto su strukturno sasvim nepodudarni:

*sklepati (šta) / uraditi (šta) na brzu ruku / preko kolena

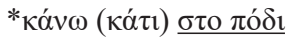

\section{Mesec u narodnim zagonetkama}

U okviru etnokulturologije, Mesec se kao denotat javlja u jednom izuzetno malom broju albanskih, grčkih i srpskih zagonetaka, kao što su naredne ${ }^{28}$ :

\begin{tabular}{|c|c|c|}
\hline $\begin{array}{l}\text { Sivac more preskoči, } \\
\text { a kopita ne skvasi. }\end{array}$ & $\begin{array}{l}\text { Naš zelenko pro polja pođe, } \\
\text { za trag mu se i ne zna }\end{array}$ & $\begin{array}{l}\text { Moj đogo preko mora pređe, } \\
\text { a kopita ne skvasi. }\end{array}$ \\
\hline & $\begin{array}{c}\text { Puno polje čavki, } \\
\text { među njima kos, } \\
\text { pokunjio nos. } \\
\text { (rešenje: zvedze i mesec) }\end{array}$ & \\
\hline & $* * * * *$ & \\
\hline
\end{tabular}

${ }^{28}$ Prevod zagonetki na srpski je naš. 
Predrag Mutavdžić, Merima Krijezi, Ana Sivački, Mesec u frazeologizmima u savremenom ...

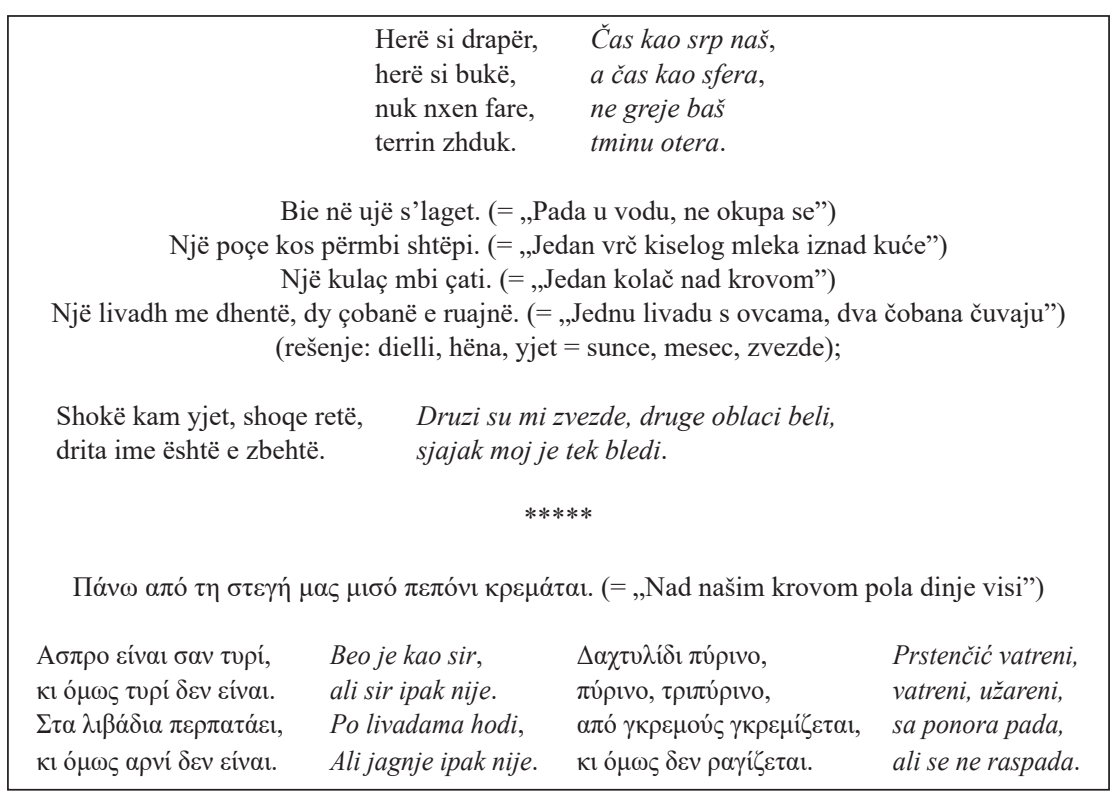

Kako se može videti iz priloženog, rimovanje zagonetki postignuto je samo u albanskom i u grčkom jeziku. U srpskim zagonetkama, koje je svojevremeno zabeležio Stojan Novaković, ${ }^{29}$ Mesec je dat u vidu teriomorfnog božanstva, a zajednička veza između njega i konja predstavlja, kako se vidi u prvoj zagonetki, karakteristična siva boja.

Za prvu i drugu grčku zagonetku simbol Meseca predstavlja kulinarizam, a u zavisnosti od doživljaja boje, on je ili žut kao dinja ili beo kao sir. U trećoj zagonetki, kada se nalazi u fazi punog Meseca, izjednačen je sa prstenom.

Kod Albanaca, Mesec je predstavljen ili kao kulinarizam (kolač) ili kao posuda (od gline) sa jasno naglašenom njegovom pozicijom u prostoru i upotrebom hromatske i ponovo kulinarske leksike.

\section{Umesto zaključka}

Na osnovu sprovedene analize frazeologizama zabeleženih u sva tri posmatrana savremena balkanska jezika - albanskom, grčkom i srpskom - nameće se nekoliko veoma interesantnih zaključaka po pitanju semantičke i morfosintaksičke ekvivalencije u prvom redu, ali i uloge Meseca u odgovarajućim kulturološkim okruženjima:

a) između analiziranih frazeoloških konstrukcija uglavnom preovlađuje nulti stepen podudarnosti posebno u strukturnom, a slično i u semantičkom pogledu,

${ }^{29}$ Natko Nodilo, Stara vjera u Srba i Hrvata. Split: Logos, 1981, str. 598. 
što nedvosmisleno ukazuje da su razmatrane frazeološke slike idiotipične i svojstvene svakom jeziku ponaosob;

b) najveći broj zabeleženih frazeologizama sa ključnom rečju mesec pripada albanskom jeziku, što nije začuđujuće, po nama, iz dva važna razloga:

- po svemu sudeći, ovo je nebesko telo imalo, i to najverovatnije u ranijim istorijskim periodima, u svesti, kulturi, verovanjima i obredima Albanaca izuzetno važnu ulogu (sasvim moguće magijsko-ritualnu) o kojoj se danas vrlo malo (ili gotovo nimalo) i nedovoljno zna, i

- drugo, Albanci su zbog svog specifičnog (stolećima izolovanog) načina života te njihovih posebnih etnogenetskih i kulturoloških odlika kao naroda u ovim frazeologizmima sačuvali do današnjih dana srž jednog niza praiskonskih indoevropskihh verovanja o Mesecu i o njegovim uticajima na čoveka, i to mnogo više nego što to izražavaju grčki i srpski frazeologizmi. Upravo frazeološki primeri na albanskom nedvosmisleno potvrđuju da je Mesec bio posmatran i poštovan kao pravi ženski simbol u indoevropskoj mitologiji, odnosno kao žensko božanstvo - takva potvrda apsolutno odsustvuje u srpskim i grčkim frazeologizmima, s obzirom da se kod ovih naroda odnos prema Mesecu vremenom promenio;

c) imajući prethodno rečeno na umu, ističemo da se ovi frazeologizmi u sva tri jezika (ali i ne samo u njima!) mogu sagledati kao svojevrsni jezički relikti petrificiranih shvatanja iz paganskog doba koji su uspešno odoleli zubu vremena, svim društvenim i kulturnim promenama i na koje bitniji uticaj nisu imali ni kasnije hrišćanstvo, ni islam - izuzetak je u ovom pogledu jedino albanski frazeogizam si hëna për bajram - s obzirom na to da nose u sebi večne istine, narodna zdravorazumska promišljanja i saznanja (samo u pojedinim slučajevima su ove konstrukcije unekoliko modifikovane i prilagođene, pri čemu je nužno došlo do promenene njihove prvobitne semantike);

d) kako su frazeologizmi sa leksemom mesec u sva tri razmatrana jezika idiotipični, nemoguće je govoriti o pravim međuleksičkim, međujezičkim i međusemantičkim podudarnostima. Činjenica je da one postoje, ali to su tek retki slučajevi;

e) kada je reč o datim prevodnim ekvivalentima za svaki frazeologizam sa leksemom mesec, nastojali smo da budemo što precizniji i tačniji u iznalaženju odgovarajućeg semantičkog parnjaka, što je u izvesnom broju slučajeva rezultiralo prevodnim ekvivalentima u vidu nefrazeoloških izraza;

f) kako se vidi na osnovu konceptualnog pristupa, analizirani frazeologizmi denotiraju različite pozitivne ili negativne ljudske osobine i karakteristike, čovekovo unutrašnje, duhovno stanje i emocije, ali i fizički izgled. Pored toga, Mesec se ne povezuje samo sa pojavom izvesnih specifičnih bolesti, nego i figurira u izrazima za označavanje koncepta temporalnog trajanja, ponavljanja ili retkog dešavanja, što se povezuje sa promenom mesečevih mena, koje su, pak, poslužile i za opisivanje čovekove unutrašnje promenljivosti i nestalnosti; 
g) svaki od tri posmatrana jezika pokazuje određene jedinstvene karakteristike frazeologizacije koje u najvećoj meri proizilaze iz kulturno-specifičnih načina posmatranja Meseca te njegovog značaja i uticaja na život čoveka;

h) analizirajući zagonetke, koje ne pripadaju frazeologiji, već narodnoj filozofiji i svetonazorima svakog naroda, utvrdili smo postojanje zanimljive povezanosti hromatske i kulinarske leksike s leksemom mesec u sva tri razmatrana jezika, kao i njene izrazite povezanosti s leksemom životinjske denominacije u srpskom.

Bez obzira na to što frazeoloških konstrukcija u čijem se sastavu nalazi konstituent mesec ima tek neznatno u odnosu na druge frazeološke tipove, kakvi su somatski, kulinarski i slični, sve analizirane konstrukcije su izuzetno značajne u kontekstu sagledavanja lingvokulturoloških, tradicijskih i mitološko-obrednih odnosa tri savremena balkanska naroda. Kako su u frazeološkim istraživanjima $\mathrm{u}$ tom smislu uvek dragoceni upravo oni izrazi koji u drugim jezicima ne poseduju svoje frazeologizovane ekvivalente, mišljenja smo da sprovedena analiza predstavlja naš skroman doprinos ne samo daljim uporednim proučavanjima frazeoloških, već i antropoloških odnosa između Albanaca, Srba i Grka.

\section{IZVORI}

a) jednojezični rečnici:

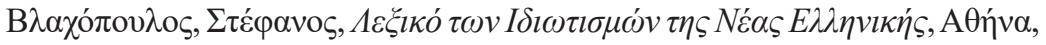

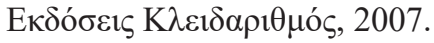

Gjevori, Mehmet, Frazeologjizma të gjuhës shqipe me shpjegime, Prishtinë, Rilindja, 1988.

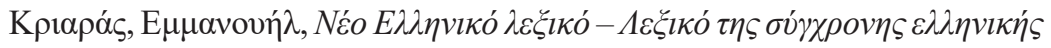

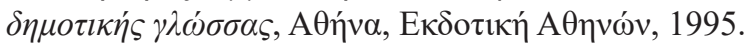

Matešić, Josip, Frazeološki rječnik hrvatskoga ili srpskoga jezika, Zagreb, Školska knjiga, 1982.

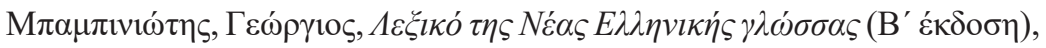

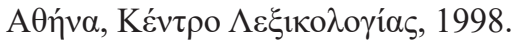

Оташевић, Ђорђе, Фразеолошки речник српског језика, Нови Сад, Прометеј, 2012.

Речник српскохрватског књижевног језика (1-6), Нови Сад, Матица Српска, 1967.

Речник српскохрватског књижевног и народног језика САНУ (том 1-19), Београд, Институт за српски језик САНУ.

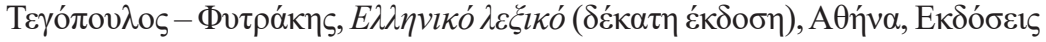
Apuovía, 1995.

Thomai, Jani, Fjalor frazeologjik i gjuhës shqipe, Tiranë, EDFA, 2010. 


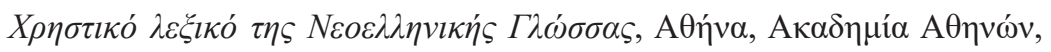
2014.

http://www.shkenca.org/content/view/5/42/

http://www.greek-language.gr/greekLang/modern_greek/tools/lexica/ triantafyllides/

b) dvojezični rečnici na balkanskim jezicima:

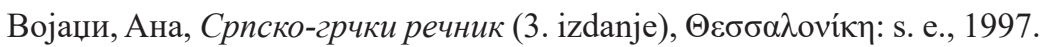

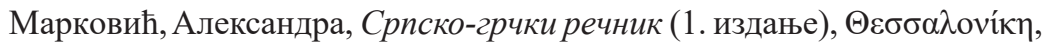

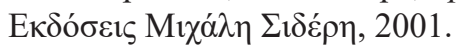

Marku, Lavdimir, Fjalor shqip-greqisht, Tiranë, Infbotues, 2010.

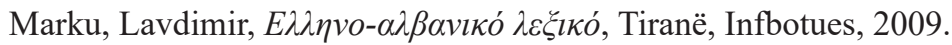

Мутавџић, Предраг, Грчко-српски речник идиома, (1. издање), Београд, ИК Јасен, 2007.

Стојановић, Миодраг - Балаћ, Александар, Грчко-српски речник (2. издање), Београд, Завод за уџбенике, 2009.

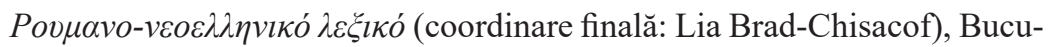
rești, Editura Demiurg, 2007.

Fjalor shqip-serbokroatisht, Prishtinë, Instituti albanologjik i Prishtinës, 1981.

Fjalor serbokroatisht-shqip, Prishtinë, Instituti albanologjik i Prishtinës, 1986.

c) dvojezični rečnici na drugim stranim jezicima:

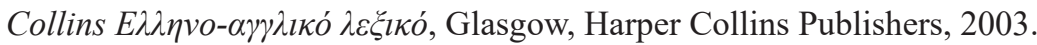

Collins Greek-English Dictionary, Glasgow, Harper Collins Publishers, 1997.

Dizionario Greco moderno-Italiano, Italiano-Greco moderno, Bologna, Zanichelli editore, 2006.

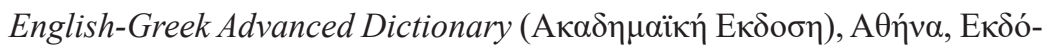

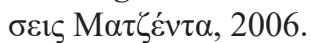

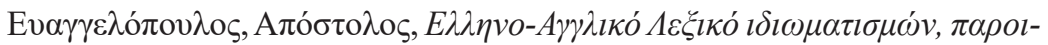

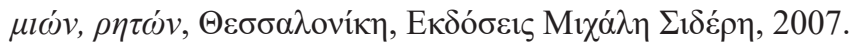

Marin, Stelios, English-Greek Lexicon of Idioms and Slang, Athens, Aheadbooks, 2005.

Marin, Stelios, Greek-English Lexicon of Idioms and Slang (2nd edition), Athens, Aheadbooks, 2010.

Mullafetahu, Agim, Fjalor idiomatik shqip-anglish, Shkup-Prishtinë-Tiranë, Logos A, 2016.

Stavropoulos, Dimitris N., Oxford Greek-English Learner's Dictionary, Oxford, Oxford University Press, 2012. 
Stavropoulos, Dimitris N., - Horby, Albert S., Oxford English-Greek Learner's Dictionary, Oxford, Oxford University Press, 2011.

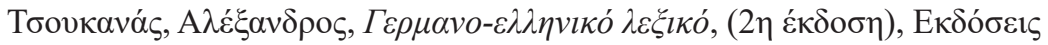

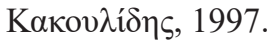

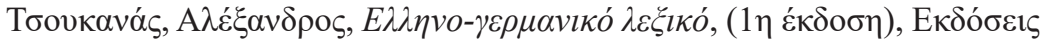

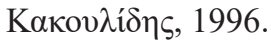

\section{d) trojezični rečnik:}

Fotea, Mircea - Țăranu, Ecaterina, Dicționar frazeologic român selectiv, cu echivalente în limbile franceză, engleză, neogreacă, Iași, Lumen, 2004.

\section{LITERATURA}

Aust, Emil, "Luna”, u: Ausführiches Lexikon der griechischen und römischen Mythologie (Wilchelm Heinrich Roscher, Hgst.), Zweiter Band 2, Zweite Abteilung, Laas - Mython, Leipzig, B. G. Treubner, 1897, str. 2154-2160.

Culianu, Ioan Petru - Poghirc, Cicerone, „Bendis”, u: Cult, magie, erezii, Articole din enciclopedii ale religiilor (editor științific: Culianu I. P.), Iași, Polirom, 2003, str. 54-55.

Čabej, Ekrem, „Život i običaji Arbanasa”, Knjiga o Balkanu 1, Beograd, Balkanski institut, 1936, str. 303-319.

Eliade, Mircea, Patterns in Comparative Religion, London-New York, Sheed \& Ward, 1958.

Elsie, Robert, A Dictionary of Albanian Religion, Mythology, and Folk Culture, New York, New York University Press, 2001.

Fiçorri, Ramiz, Mati, Vështrim i shkurtër gjeologjik, historik, eknomik, kulturor, Tiranë, Dardania, 1998.

Halimi-Statovci, Drita, Etnologjia flet, Prishtinë, Instituti Albanologjik, 1998.

Kamsi, Kolë, Besime të popullit në Labëri, Dituria No. 8 (1928), str. 309-310

Këngë popullore legjendare (Zgjedhur e pajisur me shënime nga Q. Haxhihasani), Instituti i shkencave, Tiranë, 1955, str. 91.

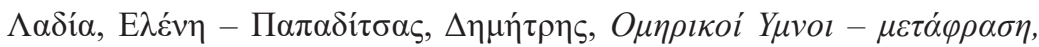

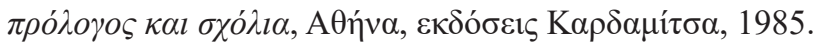

Mythologies des montagnes, des forêts et des îles, Éditeur général Pierre Grimal, Paris, Larousse Reliure, 1963.

Nodilo, Natko, Stara vjera u Srba i Hrvata, Split, Logos, 1981.

Nushi, Jani, Mitologji e besime në Myzeqe (me një parathënie nga Mark Titrja), Etnografia Shqiptare, No.5 (1974), str. 283-339.

Trebješanin, Žarko, Predstave o detetu u srpskoj tradicionalnoj kulturi, Beograd, Sofos, 1991. 
Бојовић, Злата, „Паремије у књижевном делу”, у: Србистички прилози - Зборник у част професора Славка Вукомановића (Божо Ћорић, Љубомир Поповић, Бранкица Чигоја, Александар Миловановић, уредници), Београд, Филолошки факултет, 2005, стр. 51-57.

Драгићевић, Рајна, „Концепт Бога у српским народним пословицама”, y: Теолингвистичка проучавања словенких језика (Јасмина Грковић-Мејџор и Ксенија Кончаревић, уреднице). Одељење језика и књижевности. Српски језик у светлу савремених лингвистичких теорија, Књига 5, Београд, САНУ, 2013, стр. 71-85.

Душанов законик, Текст прилагођен савременом српском језику, Београд, Ганеша клуб, 2016.

Мршевић-Радовић, Драгана, Фразеолошке глаголско-именичке синтагме у савременом српскохрватском језику, Едиција Монографија, Књига LX, Београд, Филолошки факултет, 1987.

Пејовић, Анђелка, Паремије као део етнолингвистичког наслеђа, Гласник Етнографског института САНУ, 62/2 (2014), стр. 201-214.

Чајкановић, Веселин, ,'Пуштање воде' о Великом четвртку”, у: Студије из религије и фолклора, Београд, Српски етнографски зборник, књига XXXI, Живот и обичаји, књига 13, Београд, СКА, 1924, стр. 56-84.

Чајкановић, Веселин, „Хидромантија код Филипа Вишњића”, у: 3борник у славу Филипа Вишњића и народне песме, Београд, Издање Одбора за прославу Филипа Вишњића, 1936, стр. 93-97.

Чајкановић, Веселин, Мит и религија у Срба (приредио Војислав Ђурић), Београд, СКЗ, 1973.

Predrag Mutavdžić

Merima Krijezi

Ana Sivački

\section{THE LEXEME MOON AS A KEY CONSTITUENT OF IDIOMATIC EXPRESSIONS IN MODERN ALBANIAN, GREEK AND SERBIAN}

(Summary)

The extent of mutual concordance amongst the excerted phraseological units containing the lexeme moon in Albanian, Greek, Romanian and Serbian constitutes one of the main objectives of this paper. Owing to the fact that contrastive and comparative analysis of both the internal (morphological and syntaxical) structure of phraseologisms, and their external (semantic) aspect requires consideration of a number of different linguistic and non-linguistic traits, all three languages considered herein may be perceived as both source and target. The level of concordance amongst the analyzed idiomatic expressions has been determined by formal and semantic analysis, based on which the entire corpus (consisting of 51 expressions in total) was classified in three basic broadly accepted categories of inter-phraseological equivalence: complete, partial and zero. 
Following the said analysis and considerations, we have arrived at several rather interesting conclusons primarily in terms of formal equivalence, but also with regard to the role of the Moon in the corresponding cultural surroundings. First and foremost, an overwhelming majority of the phraseologisms considered here may be classified into the zero equivalence category, which unambiguously indicates that the phraseological images these idioms contain are idiotypical of the respective languages. Another rather fascinating finding of our analysis pertains to the fact that the largest number of recorded phraseologisms is found in Albanian, which can be explained by the following: (i) the unquestionable significance of the Moon in terms of culture, beliefs, customs and rites once performed by the Albanians in the ancient times, of which our knowledge today is scarce or non-existent; (ii) due to somewhat secluded life paired with cultural and etno-genetic traits of the Albanians as a people, these phraseological units have retained the essence of primeval Indo-European beliefs of the Moon and its impact on man to a far larger extent than it is the case in Greek or Serbian phraseologisms.

Moreover, we have employed the conceptual approach as well in order to penetrate into the very perception of a variety of (human) characteristics (both physical and psychological), in addition to occurrences, emotions etc. denoted by these phraseologisms since they are to be considered as proper linguistic relics of petrified perceptions dating back all the way to the pagan era and remaining preserved even nowadays. As seen from the corpus, the idioms we consider in our analysis denote a variety of positive and negative traits or emotions, whereas we have found that the Moon is not only brought into connection with certain illnesses, but it also appears in such phraseological units that express the concept of temporal duration, repetition or rare occurrence, which can be traced back to lunar phases.

Nevertheless, since the analyzed phraseological units containing the lexeme moon are idiotypical, it is impossible to speak about proper inter-lexical, inter-lingual and inter-semantic concordances. The fact is that these do exist, but only in seldom instances. However, it is of paramount importance to emphasize that the very instances of discordance and lack of idiomatic equivalents in target languages are those to steer the attention of the researcher, for they capture and contain what makes each language, culture, tradition and worldview unique and distinctive. Therefore, we believe that the analysis presented in this paper may be considered a worthy contribution to further studying of not only phraseological but also anthropological relations amongst the Albanians, Serbs and Greeks.

Keywords: moon, idiomatic expressions, popular beliefs, Albanian, Greek, Serbian, equivalency.

Примљено 9. новембра 2018, прихваћено за објављивање 10. децембра 2020. године. 